\title{
The avifauna and conservation status of the Namuli Massif, northern Mozambique
}

\author{
PETER G. RYAN, CARLOS BENTO, CALLAN COHEN, JOHN GRAHAM, \\ VINCENT PARKER and CLAIRE SPOTTISWOODE
}

\section{Summary}

We report the current status of birds at the Namuli Massif, northern Mozambique. Despite being the only known locality for the Namuli Apalis Apalis lynesi and the nominate race of the Dapplethroat Arcanator orostruthus, the mountain is very little known ornithologically. Prior to our survey it had only been visited by an ornithologist in 1932, when Jack Vincent collected in the area for three weeks. During our week-long survey in November-December 1998 we recorded 130 bird species from the Namuli area, including all three globally threatened species reported by Vincent (Thyolo Alethe Alethe choloensis, Dapplethroat and Namuli Apalis). The higher-elevation $(>1,500 \mathrm{~m}$ ) forests are still largely intact, but most of those at lower elevations have been cleared for agriculture. The alethe and apalis are common, occurring in remnant forest patches and secondary scrub as well as pristine forest from 1,160 to $2,000 \mathrm{~m}$. The Dapplethroat is restricted to large, intact forests above $1,500 \mathrm{~m}$, but also is fairly common (up to 2-3 singing males per hectare; greater densities than recorded elsewhere). Red-rumped Swallow Hirundo daurica was recorded for the first time in Mozambique, and was suspected of breeding at $1,400 \mathrm{~m}$. We estimate that some 1,300 ha of pristine forest remains on the main massif between Gurue and Mount Namuli, but this area is being reduced by burning and "subsistence" logging. Approximately 7,000 people currently live in the area east of the main forest. Grazing by goats and pigs on the montane grasslands surrounding the forests is another problem, but the gravest threat is posed by improved road access to the area, which could open the forests to commercial logging. In addition to being the sole locality known for the Namuli Apalis and the nominate race of Dapplethroat, the Namuli forests probably support the largest single populations of Thyolo Alethe and the well-marked belcheri race of Green Barbet. These populations make Namuli arguably the most critical Important Bird Area for Mozambique, and the remaining forests have a high priority for conservation action.

\section{Introduction}

Northern Mozambique is one of the least-explored areas biologically on the African continent. Most of what we know about the region's birds results from Jack Vincent's extensive collecting trip for the British Museum in 1931-32 (Vincent 1933a). The main motivation for and highlight of this trip was the threeweek visit to the forests of the Namuli Massif in July-August 1932 (Vincent 1933a,b). The Namuli Massif is a series of large granitic domes and associated plateaux that rise up to $1,600 \mathrm{~m}$ above the surrounding plains. The forests on the slopes of Namuli form the southern limit of the Eastern Arc mountain Endemic 
Bird Area (Bibby et al. 1992a), one of the most important biodiversity sanctuaries in Africa. Vincent collected two species new to science at Namuli: the enigmatic Dapplethroat Arcanator orostruthus, two other races of which have since been found on the Usumbara and Udzungwa Mountains in Tanzania (Keith et al. 1992), and the Namuli Apalis Apalis lynesi, which is restricted to Namuli and is Mozambique's only endemic bird. Other threatened or rare taxa Vincent found at Namuli included Thyolo Alethe Alethe choloensis and the belcheri race of Green Barbet Stactolaema olivacea (Collar et al. 1994).

Nothing more has been published on the birds of Namuli; the area apparently has not been visited by birdwatchers or ornithologists since 1932 (Collar and Stuart 1985, 1988). Despite this, Namuli was ranked joint thirty-seventh of 76 important forests in a review of the key forests for threatened birds in the Afrotropical and Malagasy regions (Collar and Stuart 1988). It scored higher than Uganda's Impenetrable Forest and Kenya's Kakamega Forest, both of which have received considerable study and conservation attention. There is thus an urgent need to gain an up-to-date assessment of the status of the forests at Namuli and their birds (Collar and Stuart 1985, 1988). Such an assessment is crucial given the rapid exploitation of timber resources in many parts of Mozambique since the cease-fire in the early 1990 s that ended 20 years of civil war and unrest (e.g. Ryan 1995). In this paper we report on the avifauna of Namuli, the extent of the forests, and current resource use practices. We also make recommendations for the conservation of the area's remaining forests.

\section{Study area}

The Namuli Massif $\left(15^{\circ} 22^{\prime} \mathrm{S}, 37^{\circ} \mathrm{O2}^{\prime} \mathrm{E}\right)$ is the largest mountain range in northern Mozambique, and forms the main watershed for the region (Vincent 1933b). The nearest montane area of similar stature is Mount Mulanje, south-eastern Malawi, some $160 \mathrm{~km}$ to the south-west. The Namuli Massif is a series of spectacular granitic outcrops that tower over the relatively flat, 80o-m-high plateau of northern Mozambique. The highest peak, Mount Namuli, is 2,412 $\mathrm{m}$ high, and several other peaks are over $2,200 \mathrm{~m}$. Areas above $1,200 \mathrm{~m}$ extend some $50 \mathrm{~km}$ east-west, and $30 \mathrm{~km}$ north-south, but the massif is dissected by several river valleys (Figure 1 ). The highest peaks and largest single area above 1,500 $\mathrm{m}$ lies directly north of the regional centre of Gurue. This is the area visited by Vincent in 1932, and is where we focused our attention. Official 1:50,000 topographical maps of the area have few names for features in this area, so we use those given by Vincent (1933b).

The massif is characterised by a mosaic of montane forest, grassland and large granite whalebacks (Vincent 1933b). Edaphic factors (notably soil depth) appear to determine the nature of the vegetation, modified by aspect, slope and human activities (including fire and possibly grazing by livestock). The high-elevation grasslands (above 1,500 m), dominated by Themeda triandra (Vincent 1933a) are relatively short $(<0.5 \mathrm{~m})$ and grow on shallow soils on steep slopes or in boggy hollows. It is unlikely that they accumulate sufficient fuel loads to burn annually, at least on the steeper slopes. By comparison, the lower-elevation grassland areas (below $1,500 \mathrm{~m}$ ) are taller, with considerable amounts of bracken and some woody shrubs, including Protea sp. They would probably revert to woodland or 


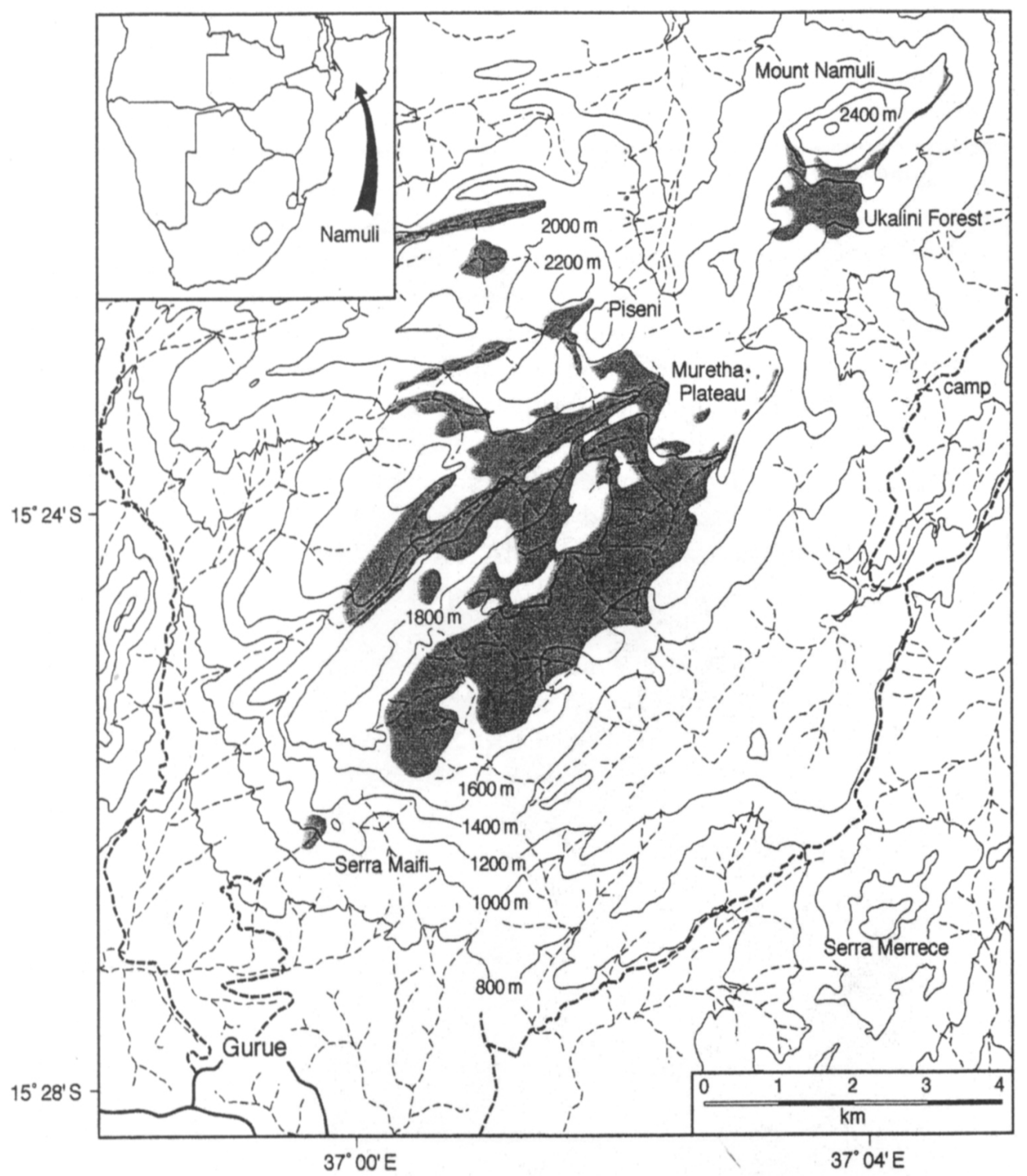

Figure 1. The Namuli Massif, northern Mozambique, with 1,000 m, 1,200 m, 1,500 $\mathrm{m}$ and $2,000 \mathrm{~m}$ contours shaded. Lines denote roads and tracks (dashed). The main study area (boxed) is repeated in greater detail in Figure 2.

forest if not burned regularly. The lower slopes of the mountain $(<1,000 \mathrm{~m})$ have extensive tea plantations, and smaller stands of exotic timber (pines and eucalypts).

\section{Methods}

We visited the Namuli Massif from 27 November to 4 December 1998. Observations were concentrated around two camps: Camp I (three days) in largely intact forest at $1,550 \mathrm{~m}$ and Camp 2 (three days) in relict riparian forest bordered by a mosaic of small fields and secondary growth at $1,250 \mathrm{~m}$ (Figure 2). Camp 1 is in Vincent's (1933b) "Ukalini Forest" and Camp 2 is at the lower limit of his "Ukusini Forest". Brief observations were made at two other sites: Camp 3 (one day) 


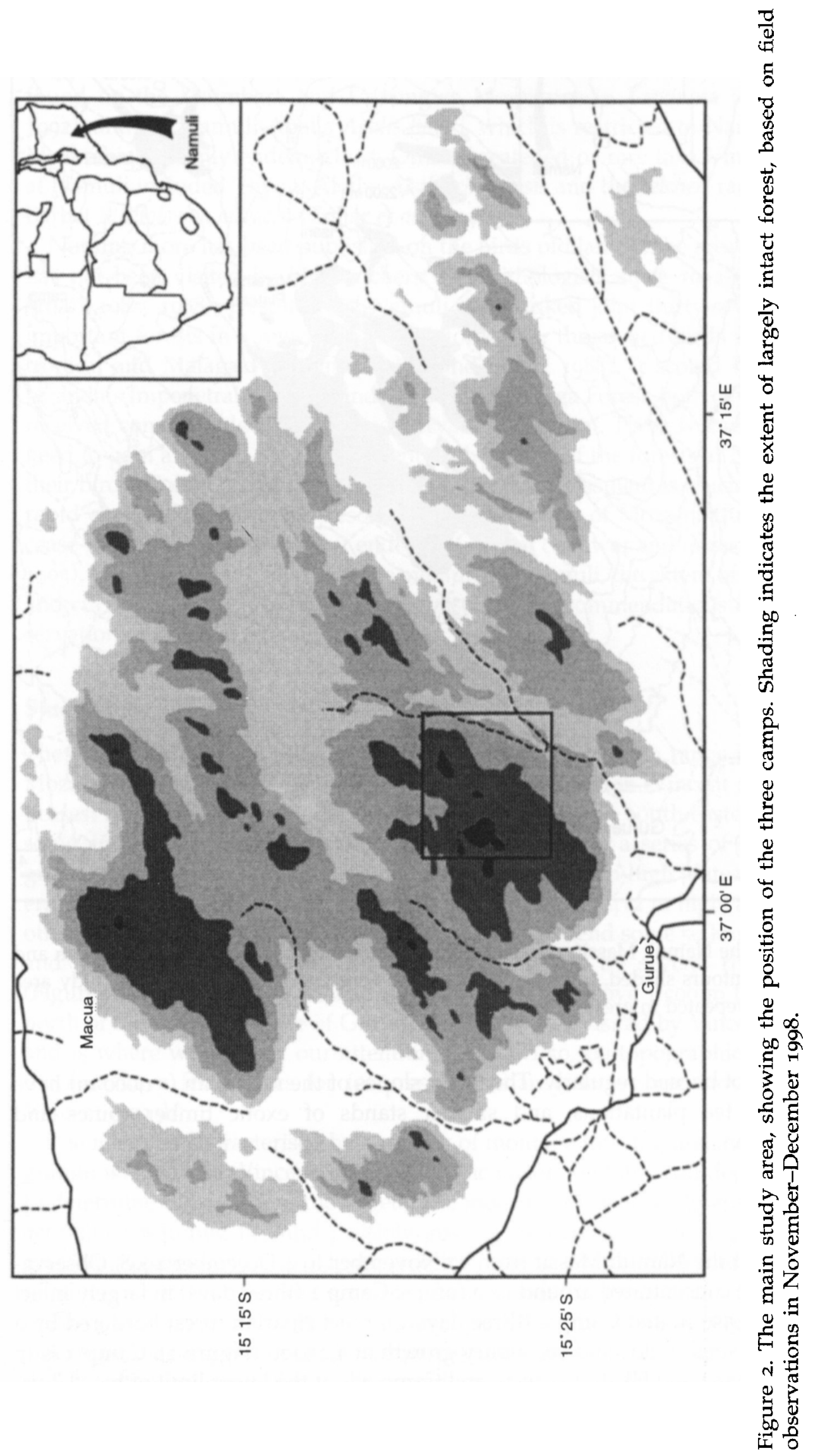


in similar habitat to Camp 2 at 1,160 m, and Gurue (one day), where we climbed to $1,400 \mathrm{~m}$ to a small patch of relict forest on the steep slopes of Serra Maifi. We explored the areas surrounding each camp, including a one-day visit to the Muretha Plateau and the extensive forest blocks south-west of this plateau, between the Serra Maifi and the twin peaks of Pilani and Peseni (Figure 2).

We recorded all bird species seen at each camp. After spending two days familiarizing ourselves with the local avifauna, we estimated the density of forest birds with point counts, using the two counting band method (Bibby et al. 1985, 1992b). This entails recording and estimating the distance between the observer and all birds detected, either by call or direct observation. Birds recorded were placed into two distance categories: less that $20 \mathrm{~m}$ or more than $20 \mathrm{~m}$ from the observer. Each point count lasted five minutes; this relatively short duration was chosen to reduce the likelihood of counting the same individuals more than once. We waited quietly for at least two minutes before starting a point count, to minimise disturbance by the observer. All points were at least $100 \mathrm{~m}$ apart. Most counts were conducted by one observer (CB), with additional counts by $\mathrm{CC}$ and PGR.

Up to five mist nets were erected on two days each at Camps 1 and 2. Nets typically were opened at dawn, and checked regularly throughout the day. Most netting was random, but tapes were used to lure Namuli Apalis (Camp 2, n=2) and Evergreen Forest Warbler Bradypterus mariae (Camp 1, $n=1$ ) into nets set to target specific birds. Birds caught were weighed, measured, banded, and blood samples collected for genetic analysis. Samples are stored at the Percy FitzPatrick Institute, and are available for analysis on request.

We interviewed local village leaders to find out how many people lived in the area immediately adjacent to the forests, how long they had lived there, what use they made of the forests, and their views on the likely future use of the forests. The current area of the forests was estimated by sketching their extent from several vantage points and then plotting these onto the 1:50,000 maps of the area. The maps were then digitized and planar areas calculated. We estimated the rate of forest loss and degradation by comparing the current extent and condition of the forests (determined by direct observation and use of 1996 Landsat $^{\mathrm{TM}}$ satellite imagery) with aerial photographs taken in 1966 and Vincent's (1933b) thorough description and photographs of the area. Unfortunately aerial photographs and satellite imagery were not available for the entire massif, but there was adequate coverage of the core study area.

\section{Results}

We recorded 130 bird species at Namuli. Combining these with the 68 species reported above $1,350 \mathrm{~m}$ by Vincent (1933a) gives a species list of 138 species (Appendix). Species richness was greater at lower elevations (Camp 2 had 90 species compared with 64 at Camp 1), despite greater search effort at higher elevations. Several species were absent from lower elevations, however, where there was no intact forest remaining. These included Rameron Pigeon Columba arquatrix, Lemon Dove Aplopelia laruata, Bar-tailed Trogon Apaloderma vittatum, Green Barbet Stactolaema olivacea, Dapplethroat, Olive Thrush Turdus olivaceus, Orange Ground-thrush Zoothera gurney, Olive-flanked Robin-chat Cossypha anom- 
ala, Yellow-throated Woodland-warbler Phylloscopus ruficapilus, Malawi Batis Batis dimorpha and Eastern Double-collared Sunbird Nectarinia mediocris. Species recorded only on the high elevation grasslands included Striped Flufftail Sarothrura affinis, Wailing Cisticola Cisticola lais and African Pipit Anthus cinnamomeus.

Almost all species reported by Vincent (1.933a) were still found in the area. The only notable exception was the Crowned Eagle Stephanoaetus coronatus, which Vincent saw daily, and we failed to encounter. Some of the species we recorded which Vincent failed to observe are summer migrants (e.g. various swallows), but his failure to see others is surprising (e.g. Green-backed Camaroptera Camaroptera brachyura, which was common up to at least $1,600 \mathrm{~m}$ ). We saw Shelley's Francolin Francolinus shelleyi on several occasions, but it was not recorded by Vincent, possibly because of intensive trapping of francolins during his visit (Vincent 1933b). Some species were patchily distributed; e.g. the large Silvery-cheeked Hornbill Bycanistes brevis was not reported by Vincent, and was seemingly absent from the main forest area, but was fairly numerous in the remnant forest on the scarp above Gurue. Red-rumped Swallows Hirundo daurica apparently have not previously been recorded from Mozambique (Dowsett and Dowsett-Lemaire 1993); a pair appeared to be breeding on rocky outcrops in grassland and bracken at 1,400 m. A single Red-rumped Swallow also was seen foraging among other swallows over the Monte Branco Tea Estate outside Gurue at $850 \mathrm{~m}$.

We made 72 five-minute point counts: 54 in the Camp 1 (Ukalini Forest), 12 in forest patches on the Muretha Plateau and the eastern slopes of Peseni, and six in lower-elevation forestarnund Samn.2. There were too few rounts

to allow separation of the different areas sampled, despite clear elevational differences. A total of 764 birds from 40 species was recorded during the point counts (Table 1). Eastern Olive Sunbird Nectarinia olivacea was the bird with the greatest estimated density, even though more Namuli Apalis were counted (the difference being due to the apparently greater detection range for the apalis). Altogether 17 species with densities exceeding two birds per hectare were recorded, including all three globally threatened species (Table 1). These density estimates are rather crude and should be treated with caution, because many birds were recorded by song, where distance to the bird is very hard to estimate. If observers actually placed birds within $30 \mathrm{~m}$ into the "close" category, it would result in the estimated densities falling by more than half. Despite this possible source of error, incidental observations on distances between pairs generally support the values obtained, at least for species of conservation concern (see below).

A total of 64 birds from 16 species was caught in mist nets, at an average rate of 4.8 birds per 100 metres of net per hour. The catch rate at Camp 1 ( 4.3 birds per 100 metres of net per hour) was slightly lower than that at Camp 2 (5.2), and there were marked differences in species composition between the two camps. Little Greenbul Andropadus virens was much more abundant at lower elevations (in fact the only Little Greenbul recorded from Ukalini Forest was the one netted), whereas White-starred Robins Pogonocichla stellata were caught more frequently higher up. We summarize the weights of birds caught in Table 2, because there are few published weight data for several of these species. 
Table 1. Numbers and densities of birds counted in 72 five-minute spot counts in the forest at Namuli during November-December 1998. Species counted fewer than 10 times are omitted $(n=22)$.

\begin{tabular}{lrrrrr}
\hline Species & \multicolumn{3}{c}{ Numbers counted } & Density \\
\cline { 2 - 4 } & Total & $<20 \mathrm{~m}$ & $>20 \mathrm{~mm}$ & (no.ha $^{-1}$ \\
\hline Eastern Olive Sunbird Nectarinia olivacea & 74 & 65 & 9 & $\mathbf{1 7 . 2 3}$ \\
Namuli Apalis Apalis lynesi & 118 & 73 & 45 & $\mathbf{1 2 . 5 7}$ \\
Stripe-cheeked Greenbul Andropadus milanjensis & 34 & 32 & $\mathbf{2}$ & $\mathbf{1 0 . 6 5}$ \\
White-tailed Crested Flycatcher Trochocercus albonotatus & 44 & 38 & 6 & 9.69 \\
Thyolo Alethe Alethe choloensis & 45 & 37 & 8 & 8.59 \\
White-starred Robin Pogonocichla stellata & 35 & 31 & 4 & 8.39 \\
Malawi Batis Batis dimorpha & 30 & 27 & 3 & 7.63 \\
Livingstone's Turaco Turaco livingstonii & 75 & 37 & 38 & 5.64 \\
Yellow-streaked Greenbul Phyllastrephus flavostriatus & 21 & 19 & 2 & 5.46 \\
Eastern Double-collared Sunbird Nectarinia mediocris & 23 & 20 & 3 & 5.18 \\
Evergreen Forest Warbler Bradypterus mariae & 21 & 18 & 3 & 4.52 \\
Eastern Saw-wing Psalidoprocne orientalis & 41 & 24 & 17 & 3.99 \\
Square-tailed Drongo Dicrurus ludwigii & 15 & 12 & 3 & 2.67 \\
Black-headed Apalis Apalis melanocephala & 15 & 12 & 3 & 2.67 \\
Yellow White-eye Zosterops senegalensis & 32 & 16 & 16 & 2.45 \\
Dapplethroat Arcanator orostruthus & 16 & 12 & 4 & 2.45 \\
Little Greenbul Andropadus virens & 22 & 13 & 9 & 2.17 \\
Yellow-rumped Tinkerbird Pogoniulus bilineatus & 17 & 5 & 12 & 0.65 \\
Total (including species where n<10) & 764 & 533 & 231 & 118.17 \\
\hline
\end{tabular}

${ }^{2}$ Estimated as $D=\log _{e}\left(n / n_{2}\right) . n /\left(m \pi r^{2}\right)$ after Bibby et al. 1985, 1992b, but values should be treated with caution (see Results and Discussion).

Table 2. Birds caught in mist-nets at Mount Namuli during November-December 1998 in relation to netting effort (length of nets $x$ hours open, $h$ ). Mean (SD) of masses are presented

\begin{tabular}{lcccc}
\hline Species & $\begin{array}{c}\text { Camp I } \\
(718 \mathrm{~h})\end{array}$ & $\begin{array}{c}\text { Camp } 2 \\
(624 \mathrm{~h})\end{array}$ & $\begin{array}{c}\text { Total } \\
(1342\end{array}$ & $\begin{array}{c}\text { Mass } \\
\text { (g) }\end{array}$ \\
\hline White-tailed Crested Flycatcher Trochocercus albonotatus & 7 & 6 & 13 & $8.7(0.9)$ \\
Little Greenbul Andropadus virens & 1 & 9 & 10 & $25.3(1.9)$ \\
Eastern Olive Sunbird Nectarinia olivacea & 3 & 5 & 8 & $10.7(1.2)$ \\
White-starred Robin Pogonocichla stellata & 6 & 1 & 7 & $18.4(2.2)$ \\
Thyolo Alethe Alethe choloensis & 2 & 3 & 5 & $41.3(2.1)$ \\
Namuli Apalis Apalis lynesi & 2 & 2 & 4 & $11.4(0.6)$ \\
Placid Greenbul Phyllastrephus placidus & 2 & 1 & 3 & $27.7(3.8)$ \\
Malawi Batis Batis dimorpha & 3 & 0 & 3 & $11.9(0.8)$ \\
Yellow-streaked Greenbul Phyllastrephus flavostriatus & 0 & 2 & 2 & $36.8(3.3)$ \\
Dapplethroat Arcanator orostruthus & 2 & 0 & 2 & $33.8(1.3)$ \\
Black-throated Wattle-eye Platysteira peltata & 0 & 2 & 2 & $15.3(1.1)$ \\
Stripe-cheeked Greenbul Andropadus milanjensis & 1 & 0 & 1 & $35.8(-)$ \\
Red-capped Robin-chat Cossypha natalensis & 0 & 1 & 1 & $31.0(-)$ \\
Evergreen Forest Warbler Bradypterus mariae & 1 & 0 & 1 & $19.6(-)$ \\
Eastern Double-collared Sunbird Nectarinia mediocris & 1 & 0 & 1 & $8.6(-)$ \\
Red-faced Crimson-wing Cryptospiza reichenozii & 0 & 1 & 1 & $11.8(-)$ \\
& 31 & 33 & 64 & \\
\hline
\end{tabular}




\section{Globally threatened species}

Namuli Apalis This was one of the most abundant birds, occurring both in the lower and mid-storey of forest interiors, as well as along forest edges. It was also found in small remnant forest patches and areas that appeared to be secondary regrowth. One pair occupied a patch of scrub no larger than $20 \times 10 \mathrm{~m}$, surrounded by unsuitable habitat (fields, rank grass and bracken). It was observed throughout the main massif, from $1,160 \mathrm{~m}$ at Camp 3 up to at least 2,000 $\mathrm{m}$ on the slopes of Peseni. It was scarce, however, in the small forest patch above Gurue, where only one bird was seen (at approximately $1,350 \mathrm{~m}$ ) in several hours of observations, including song playback. Elsewhere, Namuli Apalis responded vigorously to playback (counter-singing and/or approaching the speaker), so their apparent scarcity above Gurue is likely to be real.

The Namuli Apalis was the species most often counted during point counts, with an estimated abundance in excess of 10 birds per hectare (Table 1 ). This estimate does not appear excessive. Around Camp 2 the linear system of gallery forest supported at least seven pairs along a 500-m length of river (forested area approximately $\mathrm{I}$ ha). Similarly, in the higher elevation forests we repeatedly encountered pairs within 10-20 m of each other, suggesting rather small territories. Most occurred in pairs, and song playback frequently triggered boundary disputes between adjacent pairs.

Breeding was recorded for the first time for this species. We found a nest under construction near Camp 2 on 29 November. The nest was located approximately $4 \mathrm{~m}$ up in the slender, outer branches of an 8-m-high sapling in the gallery forest. The nest, a typical apalis ball nest with a side entrance, was suspended over the river, some $6 \mathrm{~m}$ above the water. The nest was abandoned before it was completed, but the approximate external dimensions were: $100 \mathrm{~mm}$ tall, $75 \mathrm{~mm}$ wide, and with the entrance hole some $40 \mathrm{~mm}$ in diameter. The only female caught had a large, well-developed brood patch. Other pairs had already completed breeding, with several pairs observed attending fledged young. The fledglings were identifiable by their fleshy, yellow gapes, and lacked any black on the throat and breast (this area being all slate grey).

Vincent $(1933 \mathrm{C})$ reported considerable variation in the extent of grey feathering in the black throat and breast, and suggested this was an immature feature. We found that males tended to have fully black breasts, whereas females (sexed by calls) had a grey border beneath the black breast. Females also had a slightly paler eye (cream rather than yellow). Vincent (1933c) described the feet as "brown ochre", whereas we considered them to be flesh-pink.

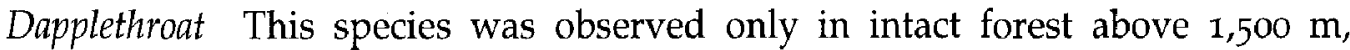
occurring up to at least $1800 \mathrm{~m}$ in the Ukalini Forest. It proved to be remarkably common within this habitat, however. Point counts, which probably only recorded singing males, estimated the density at 2.5 birds per hectare (Table 1 ), which is consistent with estimated distances between singing birds of approximately $50 \mathrm{~m}$ around Camp 1 . In the early morning this species was the dominant voice in the dawn chorus. Birds continued to sing for several hours after sunrise, occasionally even singing in the middle of the day. They tended to remain in 
fairly dense understorey vegetation, seldom venturing into view, but responded to playback, especially at dawn.

Of the two birds caught in mist nets, one had a brood patch while the other had commenced primary moult $\left(4^{2} 20^{6}\right)$, suggesting that it had completed breeding. Both birds were similar to the description of the sole nominate specimen (Vincent 1933c), differing from the other races in being more rufous brown above (olive-brown contour feathers and chestnut tail and wings) and only very lightly mottled on the breast. Vincent recorded the bill of the type specimen as black (Vincent 1933c), whereas those of the birds we netted was dark horn with a flesh-coloured base to the lower mandible and a slightly paler tip, which is similar to that reported for the other two races (Keith et al. 1992). Given that only one specimen has been collected previously, the measurements of the two birds netted are presented here: mass $34.7,32.9 \mathrm{~g}$; wing 90, $85 \mathrm{~mm}$; tail 70, $69 \mathrm{~mm}$; tarsus both $28.0 \mathrm{~mm}$, total head $40.8,41.7 \mathrm{~mm}$; culmen to skull 20.0, to feathers 17.7, to nares 11.0, 10.4 mm; bill depth at base 5.0, $4.8 \mathrm{~mm}$; width at base $5.6 \mathrm{~mm}$.

Thyolo Alethe This species also was remarkably abundant and widespread, occurring from $1,160 \mathrm{~m}$ at Camp 3 to at least $1,850 \mathrm{~m}$ in the Ukalini Forest. It typically occurred on or close to the ground in forested areas with fairly open understorey, but also ventured outside of forest into dense Brachystegia woodland near Camp 2. Point counts estimated the density at around 8 birds per hectare (Table 1). This was hard to confirm in the large forest blocks, but the numbers along the linear gallery forest system at Camp 2 approached this density (at least three pairs along $500 \mathrm{~m}$ of river). One bird caught was recently fledged, suggesting that breeding occurred in September-October. All the adult birds handled were rather pale beneath, but it is debatable whether this is sufficient to warrant subspecific status for the Namuli population (cf. Vincent 1933c).

Green Barbet (race belcheri) This well-marked race of Green Barbet was regular in intact forest from $1,300 \mathrm{~m}$ (above Gurue and south of Peseni) to at least $1,800 \mathrm{~m}$ (Ukalini and Peseni forests). Point counts suggested that their density was only 0.1 birds per hectare, but this is likely to be an underestimate of their abundance because they occur chiefly in the canopy, and are easily overlooked if not calling. Almost all birds were detected by their monotonous chop call.

\section{Forest area}

The Ukalini Forest is at least 80 ha, and its extent appears unchanged compared with the 1966 aerial photographs or even Vincent's (1933b) photographs taken in 1932. Similarly, the Muretha Plateau and other areas above 1,500 m photographed by Vincent (1933b) appear to have remained largely untouched. Of the lower-lying Ukusini Forest, only a narrow strip of gallery forest remains. However, this is not a recent development, because there is no sign of forest in this area on the 1966 aerial photographs.

Despite visiting the Muretha Plateau, Vincent makes no reference to the extensive forest that extends south from the plateau towards Gurue. He mentions having insufficient time to explore the "southern portion" (1933b, p. 320) and apparently did not discover this forest, which is concealed from view unless one 
walks to the southern edge of the Muretha Plateau. We only had time to map the northern edge of this forest (Figure 1), which is considerably larger than Ukalini Forest. Its northern boundary corresponded closely with that shown in the 1966 aerial photographs. Assuming that the southern boundaries remain as they were in 1966 (which seems likely, based on observations from Gurue and examination of satellite imagery), the area of this forest exceeds 1,000 ha. There is only one small patch of forest left on the steep scarps of the Serra Maifi above Gurue. Including Ukalini and other smaller patches, the total estimated forest area between Mount Namuli and Gurue is 1,300 ha.

We inferred the distribution of forest on other peaks in the massif by direct observation or by examining aerial and satellite photographs (only available for the area $15^{\circ} 15^{-} 30^{\prime} \mathrm{S}, 36^{\circ} 45^{\prime}-37^{\circ} \mathrm{Oo}$ 'E). There are no forest patches larger than 10 ha on the high peaks west of the study area, and we could not see any forest on the lower peaks to the east. No significant patches were visible in the parts of these areas covered by the 1966 aerial photographs. The most likely area where there may be significant other forested areas is on the large plateau north of the study area, with Macua as its highest point (Figure 1).

\section{Conservation status of the forests}

None of the area is formally conserved at present. The steep scarps that surround the main forested area on its western and southern flanks largely restrict human access. Some fields are tended up to $1,500 \mathrm{~m}$ on Serra Maifi above Gurue, but local guides indicated there were no fields beyond that point, as access over the final ridge is very difficult. The forest is accessible from the Malema River valley north-east of Gurue, an area that currently supports some 7,000 people in five loose villages. This valley is reached from Gurue by a steep track that was being upgraded during our visit. The locals report that their ancestors arrived in the area towards the end of the nineteenth century, with a large influx during the 1940s. Currently, homesteads occur up to $1,350 \mathrm{~m}$, with tilled lands up to 1,400 $\mathrm{m}$ below Ukalini Forest. People grow maize, cassava and several varieties of beans, and keep goats, chickens and ducks. The local leaders reported that there are no cattle as there is "insufficient grass".

Above $1,400 \mathrm{~m}$, human activities are limited to grazing goats on the grasslands, and collecting honey and some timber from the forests. Feral pigs also occur on the grasslands, and are abundant in the boggy areas of the Muretha Plateau. Eleven carpenters live in the area east of the forest. Logging is selective, producing rough planks which are carried down from the forest, or cut logs which are left in forest streams to be washed down during floods. Locals reported that the high-elevation forest is little used, and is perceived to be not under threat because "there is plenty of farmland lower down". Despite this, the forest edge was being eroded in several areas by fires. Many fires burned during our visit, apparently started deliberately to improve grazing or to clear scrub for agriculture.

\section{Discussion}

The forest avifauna of Namuli includes one endemic species, Namuli Apalis, and three or four endemic subspecies: Dapplethroat Arcanator orostruthus orostruthus, 
Olive-flanked Robin-chat Cossypha anomala gurue (often lumped with the nominate race), Thyolo Alethe Alethe choloensis namuli and Yellow-throated Woodlandwarbler Seisercus ruficapilla quelimanensis. In addition, Namuli supports several endemic and near-endemic species belonging to the Tanganyika-Nyasa Montane Forest Group as defined by Moreau (1966). With the exception of the Dapplethroat, the avifauna is very similar to that found in the montane forests of southern Malawi (Dowsett-Lemaire 1989).

The forests at Mount Namuli are still in remarkably good shape, with probably a very similar bird community to that encountered by Vincent in 1932. The only species that might have been lost are some of the top predators (e.g. Crowned Eagle), which could have been eradicated by people for preying on livestock. The local people reported that large mammal predators such as leopard Panthera pardus, which were common in 1932 (Vincent 1933a,b), have been hunted to extinction. However, our failure to record Crowned Eagles may be because they are less obtrusive during November-December.

Perhaps the most exciting finding of our survey, beyond the fact that the forests and their birds are still present, is that the nominate race of Dapplethroat is much more common than Vincent's observations suggested. He only collected one bird and sighted another during three weeks at Namuli (Vincent 1933a). The much greater apparent abundance of this species during our survey presumably results from the birds being more vocal in November-December. On the strength of Vincent's evidence, Collar and Stuart (1985) concluded the population of the nominate race "is likely to be very small" (p. 445). We are wary about extrapolating a total population estimate from our limited observations, especially for this species, which might be rather patchy (cf. Jensen and Brogger-Jensen 1992, Dinesen et al. 1993, Collar et al. 1994). However, the densities observed around Camp I in Ukalini Forest are at least as high as those reported from any other site (maximum 0.3 pairs per hectare at Ufahiwa Forest in the Udzungwas, Collar et al. 1994). It seems likely that the Namuli population is in the low thousands, and is probably considerably larger than the surviving population of the Usumbara race amani (Newmark 1991, Collar et al. 1994). The high density of Dapplethroat at Namuli supports Stuart's (1981) hypothesis that the disjunct distribution of this species is related in part to competition with two other groundfeeding species, the Spot-throat Modulatrix Modulatrix stictigula and Palebreasted Illadopsis Trichastoma rufipennis, both of which are absent from Namuli.

Other species of global conservation concern also appear to have large, viable populations at Namuli. The population of Namuli Apalis is likely to be at least 5,000 pairs, and is probably even greater given the catholic range of habitats occupied. Its occurrence in small forest patches and secondary scrub suggests that it is unlikely to be under any threat in the near future. There is a need to determine its range throughout the Namuli Massif and to confirm its absence from adjacent highland areas of northern Mozambique.

The Thyolo Alethe is known from only 15 montane forests in southern Malawi and northern Mozambique. The population in Malawi is estimated to be 1,500 pairs at 13 sites, with 1,000 pairs on Mulanje (Dowsett-Lemaire 1987). Even taking a conservative estimate of density, the Namuli population is likely to exceed 1,000 pairs, making Namuli the single most important site for this species. There are no recent observations from Chiperoni, the other known site for Thyolo 
Alethe in Mozambique (Collar et al. 1994), but given its abundance and broad habitat tolerance at Namuli it is likely to occur in forests at this and other highlands in northern Mozambique.

Away from Namuli, the belcheri race of Green Barbet is known only from Thyolo Mountain in southern Malawi (Fry et al. 1988), where the population is at most 80 pairs (Dowsett-Lemaire 1989). The large area of intact forest at Namuli almost certainly supports more S. o belcheri, with probably more than 100 pairs. Again, we emphasize the need for caution in extrapolating from our observations primarily in Ukalini Forest; it remains to be confirmed that all species occur at similar densities throughout the larger, southern forest. Despite this caveat, however, the large proportions of global populations of four threatened bird species found at Namuli arguably make it the most critical Important Bird Area (IBA) for Mozambique.

\section{Conservation: threats and actions}

The human population abutting the forests at Namuli has increased in recent years. When Vincent visited Namuli in 1932, people lived in the valleys east and west of the main peak, but there was no sign of people above 1,200 m (Vincent 1933a,b). The 1966 aerial photographs show few huts in the valley above Camp 2 (Vincent's Ukusini Forest); this area is now fairly densely occupied, and comprises a mosaic of small fields up to $1,400 \mathrm{~m}$. Despite the local people's claims that the forests will not be used for agriculture in future, it is difficult not to envisage continued encroachment. The slopes above Gurue are already virtually devoid of forest, and fires are eroding the forest edge even in remote areas. Current extraction of timber from the forests is limited to that needed for local use and is probably sustainable at present levels. The gravest threat is that improvement to the road leading into the Malema valley east of the forests will allow access to commercial logging trucks. Given the conservation importance of the Namuli forests, these threats are sufficiently serious that the remaining forests warrant formal protection.

Effective conservation of the forests will require the involvement of and positive spin-offs for the local community. With its rich avifauna, including an endemic species, and its spectacular scenery, Namuli has considerable potential for ecotourism, which could be an important source of income for local people. The challenge will be to empower the local community to provide appropriate services to ecotourists. An ideal conservation model would be to focus ecotourism in the relatively accessible Ukalini Forest and the surrounding, scenically spectacular area between the main peak and Muretha Plateau. The more remote, southern forest should be set aside as a core wilderness area.

\section{Acknowledgements}

The survey of the Namuli Massif was funded by a BP Conservation Award, supplemented with a grant from the African Bird Club. We are extremely grateful for this support. Chip and Alexander Cathcart-Kay from Satemwa Tea Estate, Thyolo, provided valuable advice about road conditions and gave us a list of contacts in Gurue. Mr Singh and the staff at Monte Branco Tea Estate, Gurue, gave directions to reach the main Namuli Massif. PGR is grateful to the University of Cape Town for special leave to take part in the survey. 


\section{Appendix. A list of the birds observed at the Namuli Massif.}

Asterisks denote species recorded above 1,350 $\mathrm{m}$ by Vincent (1933a). The Camp 1 list includes all observations above 1,350 m, including Ukalini Forest, Muretha Plateau and the forest below Peseni (see Figure 2 for locations).

\begin{tabular}{|c|c|c|c|c|}
\hline Species & Camp I & Camp 2 & Camp 3 & Gurue \\
\hline Little Grebe Tachybaptus ruficollis & & & $x$ & \\
\hline${ }^{*}$ Hottentot Teal Anas hottentota & & & & \\
\hline Black-shouldered Kite Elanus caeruleus & & $\mathrm{x}$ & & \\
\hline${ }^{*}$ African Hawk Eagle Hieraaetus fasciatus & & & & \\
\hline Booted Eagle Hieraaetus pennatus & & $\mathrm{x}$ & & \\
\hline${ }^{*}$ Crowned Eagle Stephanoaetus coronatus & & & & \\
\hline Black-breasted Snake Eagle Circaetus pectoralis & & $x$ & & \\
\hline Steppe Buzzard Buteo buteo & $x$ & $x$ & $x$ & \\
\hline African Goshawk Accipiter tachiro & $x$ & $x$ & & $\mathrm{x}$ \\
\hline${ }^{*}$ Black Sparrowhawk Accipiter melanoleucus & & & & \\
\hline Gymnogene Polyboroides typus & & & $\mathrm{x}$ & \\
\hline Peregrine Falco peregrinus & $x$ & & & \\
\hline${ }^{*}$ Rock Kestrel Falco tinnunculus & $x$ & & & \\
\hline Shelley's Francolin Francolinus shelleyi & $\mathrm{x}$ & $x$ & & \\
\hline $\begin{array}{l}\text { "Hildebrandt's Francolin Francolinus } \\
\text { hildebrandti }\end{array}$ & $\mathrm{x}$ & $\mathrm{x}$ & & \\
\hline Helemeted Guineafowl Numida meleagris & & $\mathrm{x}$ & & \\
\hline Striped Flufftail Sarothrura affinis & $\mathrm{x}$ & & & \\
\hline Rameron (Olive) Pigeon Columba arquatrix & $x$ & & & \\
\hline${ }^{*}$ Red-eyed Dove Streptopelia semitorquata & & $\mathrm{x}$ & $\mathrm{x}$ & \\
\hline Blue-spotted Dove Turtur afer & & & $x$ & \\
\hline *Tambourine Dove Turtur tympanistria & $x$ & $x$ & & \\
\hline *Lemon (Cinnamon) Dove Aplopelia larvata & $x$ & & & \\
\hline${ }^{*}$ African Green Pigeon Treron calva & $\mathrm{x}$ & $\mathrm{x}$ & & \\
\hline ‘Livingstone's Turaco Turaco livingstonii & $x$ & $\mathrm{X}$ & $\mathrm{X}$ & $x$ \\
\hline Purple-crested Turaco Turaco porphyreolophus & & $\mathrm{x}$ & & \\
\hline African Cuckoo Cuculus gularis & & & $\mathrm{X}$ & \\
\hline Red-chested Cuckoo Cuculus solitarius & $\mathrm{x}$ & $\mathrm{x}$ & & \\
\hline Jacobin Cuckoo Clamator jacobinus & & & & $\mathrm{x}$ \\
\hline Klaas's Cuckoo Chrysococcyx klaas & & & & $\mathrm{x}$ \\
\hline Burchell's Coucal Centropus burchellii & $\mathrm{x}$ & $\grave{x}$ & & $\mathrm{x}$ \\
\hline Cape Eagle Owl Bubo capensis & & $\mathrm{x}$ & & \\
\hline *African Wood Owl Strix woodfordii & $\mathrm{x}$ & $\mathrm{x}$ & & \\
\hline Freckled Nightjar Camprimulgus tristigma & $x$ & & & \\
\hline European Swift Apus apus & & $x$ & $\mathrm{x}$ & \\
\hline Mottled Swift Apus aequatorialis & & $X$ & & $x$ \\
\hline Scarce Swift Schoutedenapus myoptilus & & & $\mathrm{x}$ & \\
\hline Narina Trogon Apaloderma narina & & & $x$ & \\
\hline *Bar-tailed Trogon Apaloderma vittatum & $\mathrm{x}$ & & & $x$ \\
\hline Half-collared Kingfisher Alcedo semitorquata & & & $x$ & \\
\hline African Pygmy Kingfisher Isipinda picta & & $x$ & & $x$ \\
\hline European Bee-eater Merops apiaster & & & $x$ & $x$ \\
\hline European Roller Coracias garrulus & & & & $x$ \\
\hline Silvery-cheeked Hornbill Bycanistes brevis & & & & $\mathrm{x}$ \\
\hline${ }^{*}$ Crowned Hornbill Tockus alboterminatus & $x$ & $x$ & & $x$ \\
\hline *Green Barbet Stactolaema olivacea & $x$ & & & $\mathrm{x}$ \\
\hline $\begin{array}{l}\text { Yellow-fronted Tinkerbird Pogoniulus } \\
\text { chrysoconus }\end{array}$ & & $X$ & & \\
\hline $\begin{array}{l}\text { *Yellow-rumped Tinkerbird Pogoniulus } \\
\text { bilineatus }\end{array}$ & $x$ & $x$ & $x$ & $x$ \\
\hline *Scaly-throated Honeyguide Indicator variegatus & $X$ & & & \\
\hline
\end{tabular}


Appendix. continued

\begin{tabular}{|c|c|c|c|c|}
\hline Species & Camp I & Camp 2 & Camp 3 & Gurue \\
\hline \multicolumn{5}{|l|}{${ }^{*}$ Lesser Honeyguide Indicator minor } \\
\hline Brown-backed Honeyguide Prodotiscus regulus & & $X$ & & \\
\hline \multicolumn{5}{|l|}{$\begin{array}{l}\text { *Green-backed Honeyguide Prodotiscus } \\
\text { insignis }\end{array}$} \\
\hline $\begin{array}{l}\text { Golden-tailed Woodpecker Campethera } \\
\text { abingoni }\end{array}$ & & $x$ & & \\
\hline${ }^{*}$ Cardinal Woodpecker Dendropicos fuscescens & & $x$ & & \\
\hline \multicolumn{5}{|l|}{ *Bearded Woodpecker Thripias namaquus } \\
\hline African Broadbill Smithornis capensis & & $x$ & & \\
\hline Wiretailed Swallow Hirundo smithii & & & & $\mathrm{x}$ \\
\hline Red-rumped Swallow Hirundo daurica & $\mathrm{x}$ & & & $\mathrm{x}$ \\
\hline${ }^{*}$ Lesser Striped Swallow Hirundo abyssinica & & $x$ & $x$ & $x$ \\
\hline *Rock Martin Hirundo fuligula & $\mathrm{x}$ & & & $\mathrm{x}$ \\
\hline House Martin Delichon urbica & & & $x$ & \\
\hline Sand Martin Riparia riparia & & & $x$ & \\
\hline Eastern Saw-wing Psalidoprocne orientalis & $\mathrm{x}$ & $x$ & $x$ & \\
\hline "Black Cuckoo-shrike Campephaga flava & & $\mathrm{x}$ & $\mathrm{x}$ & $\mathrm{x}$ \\
\hline *Square-tailed Drongo Dicrurus ludwigii & $x$ & $x$ & $x$ & $x$ \\
\hline *White-necked Raven Corvus albicollis & $x$ & & & \\
\hline *Rufous-bellied Tit Parus rufiventris & & $x$ & & \\
\hline *Black-eyed Bulbul Pycnonotus barbatus & $\mathrm{X}$ & $x$ & $x$ & $x$ \\
\hline${ }^{*}$ Little Greenbul Andropadus virens & $\mathrm{x}$ & $x$ & $\mathrm{x}$ & $\mathrm{x}$ \\
\hline $\begin{array}{l}\text { *Stripe-cheeked Greenbul Andropadus } \\
\text { milanjensis }\end{array}$ & $x$ & $x$ & & \\
\hline${ }^{*}$ Mountain Greenbul Andropadus nigriceps & $x$ & $\mathrm{x}$ & & \\
\hline *Placid Greenbul Phyllastrephus placidus & $x$ & $\mathrm{x}$ & & \\
\hline $\begin{array}{l}\text { *Yellow-streaked Greenbul Phyllastrephus } \\
\text { flavostriatus }\end{array}$ & $\mathrm{x}$ & $x$ & & \\
\hline *Dapplethroat Arcanator orostruthus & $x$ & & & \\
\hline Eastern Nicator Nicator gularis & & $\mathrm{X}$ & & \\
\hline *Olive Thrush Turdus olivaceus & $x$ & & & \\
\hline *Orange Ground-thrush Zoothera gurneyi & $x$ & & & \\
\hline Red-capped Robin-chat Cossypha natalensis & & $x$ & & \\
\hline *Cape Robin-chat Cossypha caffra & $x$ & $x$ & $x$ & $\mathrm{x}$ \\
\hline *Olive-flanked Robin-chat Cossypha anomala & $x$ & & & $x$ \\
\hline "Thyolo Alethe Alethe choloensis & $x$ & $x$ & $x$ & $\mathrm{x}$ \\
\hline "White-starred Robin Pogonocichla stellata & $x$ & $x$ & & \\
\hline *Stonechat Saxicola torquata & $x$ & $x$ & $x$ & \\
\hline *African Yellow Warbler Chloropeta natalensis & $\mathrm{x}$ & $\mathrm{x}$ & & \\
\hline *Evergreen Forest Warbler Bradypterus mariae & $x$ & $x$ & & $\mathrm{x}$ \\
\hline Broad-tailed Warbler Schoenicola brevirostris & & & $\mathrm{X}$ & \\
\hline Willow Warbler Phylloscopus trochilus & $\mathrm{x}$ & $x$ & & \\
\hline $\begin{array}{l}\text { *Yellow-throated Woodland-warbler } \\
\text { Phylloscopus ruficapilus }\end{array}$ & $\mathrm{X}$ & & & \\
\hline *Black-headed Apalis Apalis melanocephala & $x$ & $x$ & $x$ & $x$ \\
\hline Yellow-breasted Apalis Apalis flavida & & $x$ & & \\
\hline${ }^{*}$ Namuli Apalis Apalis lynesi & $\mathrm{x}$ & $x$ & $\mathrm{x}$ & $\mathrm{X}$ \\
\hline Red-faced Crombec Sylvietta whytii & & $x$ & & \\
\hline $\begin{array}{l}\text { Green-backed Camaroptera Camaroptera } \\
\text { brachyura }\end{array}$ & $x$ & $x$ & & $x$ \\
\hline $\begin{array}{l}\text { African Moustached Warbler Melocichla } \\
\text { mentalis }\end{array}$ & & $x$ & & $x$ \\
\hline Red-faced Cisticola Cisticola erythrops & & & & $x$ \\
\hline *Singing Cisticola Cisticola cantans & & $\mathrm{x}$ & & \\
\hline${ }^{*}$ Wailing Cisticola Cisticola lais & $\mathrm{x}$ & & & \\
\hline Croaking Cisticola Cisticola natalensis & & $\mathrm{x}$ & & \\
\hline
\end{tabular}


Appendix. continued

\begin{tabular}{|c|c|c|c|c|}
\hline Species & Camp 1 & Camp 2 & Camp 3 & Gurue \\
\hline Red-winged Warbler Heliolais erythroptera & & $X$ & & \\
\hline *Tawny-flanked Prinia Prinia subflava & & $X$ & & $x$ \\
\hline Spotted Flycatcher Muscicapa striata & & $x$ & & \\
\hline *African Dusky Flycatcher Muscicapa adusta & $x$ & $x$ & & \\
\hline Ashy Flycatcher Muscicapa caerulescens & & $x$ & & \\
\hline *Malawi (Cape) Batis Batis [capensis] dimorpha & $\mathrm{X}$ & & & \\
\hline Mozambique Batis Batis soror & & $x$ & & $X$ \\
\hline Black-throated Wattle-eye Platysteira peltata & & $X$ & $x$ & \\
\hline $\begin{array}{l}\text { *White-tailed Crested Flycatcher Trochocercus } \\
\text { albonotatus }\end{array}$ & $x$ & $x$ & & \\
\hline African Paradise Flycatcher Tersiphone viridis & & $x$ & $\mathrm{X}$ & $\mathrm{X}$ \\
\hline *Mountain Wagtail Motacilla clara & $X$ & $x$ & $x$ & \\
\hline${ }^{*}$ African Pipit Anthus cinnamomeus & $X$ & & & \\
\hline Striped Pipit Anthus lineiventris & $X$ & $x$ & & $\mathrm{X}$ \\
\hline *Tropical Boubou Laniarius aethiopicus & $X$ & $x$ & $X$ & $\mathrm{X}$ \\
\hline Black-backed Puffback Dryoscopus cubla & & $x$ & $\mathrm{X}$ & $\mathrm{X}$ \\
\hline Brown-crowned Tchagra Tchagra australis & $x$ & $X$ & $x$ & \\
\hline $\begin{array}{l}\text { Orange-breasted Bush Shrike Telophorus } \\
\text { sulfureopectus }\end{array}$ & & $\mathrm{X}$ & $X$ & \\
\hline $\begin{array}{l}\text { *Black-fronted Bush Shrike Telophorus } \\
\text { nigrifrons }\end{array}$ & $x$ & $x$ & $x$ & $x$ \\
\hline $\begin{array}{l}{ }^{*} \text { Grey-headed Bush Shrike Malaconotus } \\
\text { blanchoti }\end{array}$ & & & & \\
\hline $\begin{array}{l}\text { Violet-backed Starling Cinnyricinclus } \\
\text { leucogaster }\end{array}$ & & $x$ & $X$ & \\
\hline${ }^{*}$ Red-winged Starling Onychognathus morio & $x$ & & & $X$ \\
\hline $\begin{array}{l}\text { *Miombo Double-collared Sunbird Nectarinia } \\
\text { manoensis }\end{array}$ & & $\mathrm{X}$ & $X$ & \\
\hline $\begin{array}{l}\text { *Eastern Double-collared Sunbird Nectarinia } \\
\text { mediocris }\end{array}$ & $X$ & & & \\
\hline${ }^{*}$ Variable Sunbird Nectarinia venusta & & $\mathrm{X}$ & & \\
\hline *Eastern Olive Sunbird Nectarinia olivacea & $X$ & $X$ & $x$ & $x$ \\
\hline Collared Sunbird Anthreptes collaris & & $X$ & $X$ & $X$ \\
\hline $\begin{array}{l}\text { Western Violet-backed Sunbird Anthreptes } \\
\text { longuemarei }\end{array}$ & & $X$ & & \\
\hline *Yellow White-eye Zosterops senegalensis & $\mathrm{X}$ & $x$ & $x$ & $X$ \\
\hline${ }^{*}$ Forest Weaver Ploceus bicolor & $\mathrm{X}$ & $x$ & & $X$ \\
\hline Spectacled Weaver Ploceus ocularis & & $X$ & & \\
\hline Red-billed Quelea Quelea quelea & & $X$ & & \\
\hline Blue-billed Firefinch Lagonostica rubricata & & $X$ & $x$ & $x$ \\
\hline Common Waxbill Estrilda astrild & & $X$ & $X$ & $X$ \\
\hline *Eastern Swee Estrilda quartinia & $x$ & $x$ & $X$ & $X$ \\
\hline Bronze Mannikin Spermestes cucullata & & $x$ & $X$ & $X$ \\
\hline Red-backed Mannikin Spermestes bicolor & & $X$ & $X$ & \\
\hline Pied Mannikin Spermestes fringilloides & & & & $x$ \\
\hline Pin-tailed Whydah Vidua macroura & & $X$ & $X$ & \\
\hline $\begin{array}{l}\text { *Red-faced Crimson-wing Cryptospiza } \\
\quad \text { reichenovii }\end{array}$ & $X$ & $x$ & & \\
\hline${ }^{*}$ African Citril Serinus citrinelloides & & $x$ & & \\
\hline \multirow[t]{2}{*}{ Cabanis's Bunting Emberiza cabanisi } & & $X$ & & \\
\hline & 64 & 90 & 46 & $4^{8}$ \\
\hline
\end{tabular}




\section{References}

Bibby, C.J., Phillips, B.N. and Seddon, A.J. (1985) Birds of restocked conifer plantations in Wales. J. Appl. Ecol. 22: 619-633.

Bibby, C.J., Collar, N.J., Crosby, M.J., Heath, M.F., Imboden, C., Johnson, T.H., Long, A.J., Stattersfield, A.J. and Thirgood, S.J. (1992a) Putting biodiversity on the map: priority areas for global conservation. Cambridge, U.K.: International Council for Bird Preservation.

Bibby, C.J., Burgess, N.D. and Hill, D.A. (1992b) Bird census techniques. London: Academic Press.

Collar, N.J. and Stuart, S.N. (1985) Threatened bird of Africa and related islands: the ICBP/ IUCN Red Data Book. Cambridge, U.K.: International Council for Bird Preservation and International Union for Conservation of Nature.

Collar, N.J. and Stuart, S.N. (1988) Key forests for threatened birds in Africa. Cambridge, U.K.: International Council for Bird Preservation (Monogr. 3: 1-102).

Collar, N.J., Crosby, M.J. and Stattersfield, A.J. (1994) Birds to watch 2: the world list of threatened birds. Cambridge, U.K.: BirdLife International.

Dinesen, L., Lehmberg, T., Svendson, J.O. "and Hansen, L.A. (1993) Range extensions and other notes on some range-restricted forest birds from West Kilombero in the Udzungwa Mountains, Tanzania. Scopus 17: 48-59.

Dowsett, R.J. and Dowsett-Lemaire, F. (1993) A contribution to the distribution and taxonomy of Afrotropical and Malagasy birds. Turaco Res. Report 5: 1-389.

Dowsett-Lemaire, F. (1987) On the distribution, ecology and voice of two Alethe species in Malawi. Scopus 11: 25-32.

Dowsett-Lemaire, F. (1989) Ecological and biogeographical aspects of forest bird communities in Malawi. Scopus 13: 1-80.

Fry, C.H., Keith, S. and Urban, E.K. \& Fry, C.H. (1988) The birds of Africa, III. London: Academic Press.

Jensen, F.P. and Brogger-Jensen, S. (1992) The forest avifauna of the Uzungwa Mountains, Tanzania. Scopus 15: 65-83.

Keith, S., Urban, E.K. and Fry, C.H. (1992) The birds of Africa, IV. London: Academic Press.

Moreau, R.E. (1966) The bird faunas of Africa and its islands. London: Academic Press.

Newmark, W.D. (1991) Tropical forest fragmentation and the local extinction of understory birds in the eastern Usumbara Mountains, Tanzania. Conserv. Biol. 5: $67-78$.

Ryan, P.G. (1995) Exploitation of tropical hardwood trees in Mozambique. Afr. Wildl. 49(6): 18-19.

Stuart, S.N. (1981) An explanation for the disjunct distributions of Modulatrix orostruthus and Apalis (or Orthotomus) moreaui. Scopus 5: 1-4.

Vincent, J. (1933a) The birds of northern Portuguese East Africa. Comprising a list of, and observations on, the collections made during the British Museum Expedition of 1931-32. Ibis 13 (3): 611-652; 13 (4): 126-160, 300-340, 495-527, 757-799; 13 (5): 1-37, 355-397, 485-529, 707-762; $13(6): 48-125$.

Vincent, J. (1933b) The Namuli Mountains, Portuguese East Africa. Geogr. J. 81: 314-327.

Vincent, J. (1933C) [Four new species and eighteen new subspecies of birds . collected during the recent Portuguese East African Expedition]. Bull. Br. Orn. Club 53: 129-149.

PETER G. RYAN, CALLAN COHEN, JOHN GRAHAM and CLAIRE SPOTTISWOODE

Percy FitzPatrick Institute, University of Cape Town, Rondebosch 7701, South Africa. E-mail: pryan@botzoo.uct.ac.za 
CARLOS BENTO

Universidade Eduardo Mondlane, Museu de Historia Natural, PO Box 257, Maputo, Mozambique.

VINCENT PARKER

Mozambique Bird Atlas, Endangered Wildlife Trust, P. Bag X11, Parkview 2122, South Africa. 